\title{
Migração Esportiva: um olhar para os corredores de rua africanos no Brasil
}

\author{
Sports Migration: a look at African runners in Brazil
}

Migración deportiva: una mirada a los atletas africanos en Brasil

\author{
Jeferson Roberto Rojo \\ Orientador: Fernando Augusto Starepravo \\ Tese de doutorado - PEF-UEM/UEL
}

\begin{abstract}
RESUMO: A migração pode ser caracterizada a priori como a troca de residência definitiva ou temporária. Esse fenômeno é observado em diferentes setores da sociedade, bem como ocorre por diferentes motivos, e nesta pesquisa a migração se relaciona ao setor esportivo. Dentro do contexto esportivo, um dos grupos que estão em constante mobilidade migratória é o de corredores de rua oriundos de países do leste africano, o qual se desloca para diferentes países, inclusive o Brasil. Entretanto, os impactos da entrada desses indivíduos não são sempre bons, divergências e resistências são observadas por parte dos atletas nativos brasileiros, que argumentam dificuldade em competir com esses indivíduos, uma vez que são considerados os melhores do mundo nas corridas de médias e longas distâncias. Diante disso, a presente pesquisa parte do questionamento de quais fatores influenciam o processo migratório dos corredores de rua africanos para o Brasil. Frente ao problema exposto, estabeleceu-se como objetivo principal analisar os fatores que influenciam o processo migratório de atletas de corrida de rua africanos para o Brasil. Para atender a demanda estabelecida pelo objetivo, elaborou-se um modelo analítico da migração esportiva, modelo este formulado após compreensão da necessidade de agregar diferentes perspectivas para a análise do fenômeno. A ideia central do modelo proposto foi a de analisar o processo migratório a partir de quatro dimensões: dimensão cultural, dimensão política, dimensão econômica e dimensão pessoal. Para atender aos anseios do modelo analítico, a pesquisa de cunho explicativo se apropriou de múltiplas técnicas de pesquisa, bibliográfica, observacional, entrevistas e documental. Como resultados verificou-se que a migração de corredores de ruas africanos para o Brasil reflete alguns aspectos da globalização do esporte. No que tange à dimensão cultural, identificou-se uma divisão internacional do trabalho esportivo. Já na dimensão política, detectou-se a atuação de diferentes atores políticos em uma disputa pela flexibilização da migração e participação de estrangeiros em competição. Economicamente, observou-se que há um desequilíbrio entre o Brasil e os países que enviam os atletas corredores de rua, sendo que a origem dos atletas se enquadra como periférica, assim como apontado pela perspectiva do sistema mundial. Por fim, na dimensão pessoal, identificou-se que mesmo as estruturas da globalização atuando na pressão para a migração, os indivíduos são capazes de calcular os riscos em relação à sua decisão de migrar, e suas relações pessoais contribuem para conhecer os responsáveis por efetivar o processo migratório. Conclui-se então que o fator predominante para a decisão de migrar é o fator econômico. No entanto, as demais dimensões, políticas, culturais e a pessoal, moldam o padrão de migração dos corredores de rua africanos para o Brasil.
\end{abstract}

PALAVRAS-CHAVE: Atletismo. Migração. Esporte. Corrida de rua. Globalização. 
ABSTRACT: The migration can be characterized beforehand as the exchange of definite or temporary residence. This phenomenon is observed in different sectors of the society, as well as takes place for different motives; in this inquiry the migration is made a list to the sporting sector. Within the sports context, one of the groups that are in constant migratory mobility are African runners, who move to different countries, including Brazil. Meantime, the impacts of the entry of these individuals are not always quite receptive; divergences and conflicts are observed regarding the native Brazilian athletes, who argue a difficulty in competing with these individuals, as soon as those are considered the best of the world in the running of middle and long-distance. Given this, the present research starts from the question of which factors influence the migratory process of African runners to Brazil? In view of the above problem, the main objective was to analyze the factors that influence the migration process of African road running athletes to Brazil. To meet the demand established by the objective, an analytical model of sports migration was elaborated, a model formulated after understanding the need to aggregate different perspectives for the analysis of the phenomenon. The central idea of the proposed model was to analyze the migratory process from the following dimensions: cultural dimension, political dimension, economic dimension and personal dimension. To meet the desires of the analytical model, explanatory research has appropriated multiple research techniques, including bibliographic research, observational research, interviews and documentary research. As a result, it was diagnosed that the migration of East African runners to Brazil reflects some aspects of the globalization of sport. Regarding the cultural dimension, an international division of sports work was identified. In the political dimension, the performance of different political actors was detected in a dispute for the flexibility of migration and participation of foreigners in competition. Economically, it was observed that there is an imbalance between the countries part of the migration process towards the more central countries, as pointed out by the perspective of the world system. Finally, in the personal dimension, it was identified that even the structures of globalization acting on the pressure for migration, individuals are able to calculate the risks in relation to their decision to migrate, as well as their personal relationships contribute to knowing those responsible for effect the migration process. It is concluded, then, that the predominant factor for the decision to migrate is the economic one. However, the other dimensions, political, cultural and personal, shape the pattern of migration of African road runners to Brazil.

KEYWORDS: Athletics. Migration. Sport. Road running. Globalization.

RESUMEN: La migración se puede caracterizar a priori como el cambio de residencia permanente 0 temporal. Este fenómeno se observa en diferentes sectores de la sociedad, así como ocurre por diferentes motivos, en esta investigación la migración se relaciona con el sector deportivo. Dentro del contexto deportivo, uno de los colectivos que se encuentra en constante movilidad migratoria son los corredores de países de África Oriental, que se trasladan a diferentes países, incluido Brasil. Sin embargo, los impactos de la entrada de estos individuos no siempre son muy receptivos, las divergencias y resistencias son observadas por los atletas nativos brasileños, quienes argumentan una dificultad para competir con estos individuos, ya que son considerados los mejores del mundo en media y larga distancia. Por lo tanto, esta investigación parte del cuestionamiento de ¿qué factores influyen en el proceso migratorio de los atletas africanos a Brasil? Ante el problema anterior, el principal objetivo fue analizar los factores que influyen en el proceso migratorio de los atletas africanos a Brasil. Para atender la demanda establecida por el objetivo, se desarrolló un modelo analítico de migración deportiva, un modelo formulado luego de comprender la necesidad de agregar diferentes perspectivas para el análisis del fenómeno. La idea central del modelo propuesto fue analizar el proceso migratorio a partir de cuatro dimensiones: dimensión cultural, dimensión política, dimensión económica y dimensión personal. Para atender las ansiedades del modelo analítico, la investigación explicativa utilizó múltiples técnicas de investigación, bibliográfica, observacional, entrevistas y documental. Como resultado, se encontró que la migración de atletas africanos a Brasil refleja algunos aspectos de la globalización del deporte. En lo que respecta a la dimensión cultural, se identificó una división internacional del trabajo deportivo. En la dimensión política, se detectó la actuación de diferentes actores políticos en una disputa por la flexibilidad de la migración y la participación de los extranjeros en la competencia. Económicamente, se observó que existe un desequilibrio entre Brasil y los países que envían deportistas. Ya que el origen de los deportistas encaja como periférico, como apunta la perspectiva del sistema mundial. Finalmente, en la dimensión personal, se identificó que incluso las estructuras de la globalización actuando en la presión por la migración, los individuos son capaces de calcular los riesgos en lo que se refiere a su decisión de migrar, así como sus $r$ Por tanto, se concluye que el factor predominante para la decisión de migrar es 
el económico. Sin embargo, las otras dimensiones, políticas, culturales y personales, configuran el patrón de migración de los deportistas africanos a Brasil.elaciones personales contribuyen a conocer a los responsables de realizar el proceso migratorio.

PALABRAS CLAVE: Atletismo. Migración. Deporte. Pruebas de ruta. Globalización.

Disponível em: http://dx.doi.org/10.13140/RG.2.2.34770.27844

Recebido: setembro de 2021.

Aceito: setembro de 2021. 